\title{
Epidemiology of Sub-Clinical Mastitis in Dairy Cows in Urban Areas of Chittagong, Bangladesh
}

\author{
Shariful Islam ${ }^{1,2,3, a^{*}, \text { Shama Ranjan Barua }}{ }^{3,4, b}$, Ariful Islam ${ }^{1,2, c}$, Shahnaj Parvin Moni ${ }^{3, d}$, Helal Uddin ${ }^{3, e}$, \\ Jinnat Ferdous 1,2,3,f, Md Kaisar Rahman ${ }^{1,2,3, g}$, Mohammad Mahmudul Hassan ${ }^{3, h}$, A.K.M. Anisur Rahman ${ }^{5, i}$, \\ Sharmin Chawdhury ${ }^{3, j}$
}

\author{
${ }^{1}$ EcoHealth Alliance, New York, NY, USA \\ ${ }^{2}$ Institute of Epidemiology, Disease Control and Research (IEDCR), Mohakhali, Dhaka-1212, Bangladesh \\ ${ }^{3}$ Chittagong Veterinary and Animal Sciences University (CVASU), Khulshi, Chittagong-4225, Bangladesh \\ ${ }^{4}$ Department of Livestock Services, Farmgate, Dhaka, Bangladesh \\ ${ }^{5}$ Bangladesh Agricultural University, Mymensingh-2202, Bangladesh \\ *Corresponding author
}

\begin{tabular}{|c|c|}
\hline A R T I C L E I N F O & A B S T R A C T \\
\hline $\begin{array}{l}\text { Keywords: } \\
\text { Epidemiology } \\
\text { Sub-Clinical Mastitis } \\
\text { Cow } \\
\text { Bangladesh } \\
\text { Risk factors }\end{array}$ & $\begin{array}{l}\text { Mastitis is considered to be the most devastating condition for the dairy farms of low and medium } \\
\text { income countries due to its alarming impact on production and worldwide has been recognized as } \\
\text { one of the most economically significant infectious diseases affecting the welfare of dairy animal. } \\
\text { Chittagong is one of the dairy intensive regions of Bangladesh but comprehensive epidemiological } \\
\text { studies addressing prevalence of and risk factors for subclinical mastitis (SCM) are scant. Therefore } \\
\text { we aimed to approximate the prevalence of SCM in dairy cows along with the associated risk factors } \\
\text { in dairy cows of Chittagong Metropolitan Area (CMA), Bangladesh. We included } 114 \text { cross breed } \\
\text { (Holstein } \times \text { Local) lactating cows, raised at } 6 \text { dairy farms in CMA between February to November, } \\
2015 \text { for this study. California Mastitis Test (CMT) was used to assess SCM at animal level. The } \\
\text { overall prevalence of mastitis was } 34.2 \% \text { among the tested cows. Floor type, source of replacement } \\
\text { cows, history of previous reproductive disorder, stage of lactation and cleanliness of floor was found } \\
\text { significantly associated with SCM in univariate analysis. In random effect multiple logistic } \\
\text { regression model, cemented floor was found to increase the odds of SCM by } 5.03 \text { times than that of } \\
\text { brick floor. Similarly, cows with history of reproductive disorders had more risk of having SCM } \\
\text { than that of cows without a history of reproductive disorders. Since the SCM is prevalent in the study } \\
\text { area, the intervention strategy should focus on causal agent, improved management, frequent } \\
\text { monitoring of SCM in milking cows with CMT and use of teat disinfectants; with minimal or no } \\
\text { treatment with antimicrobial agents. }\end{array}$ \\
\hline
\end{tabular}

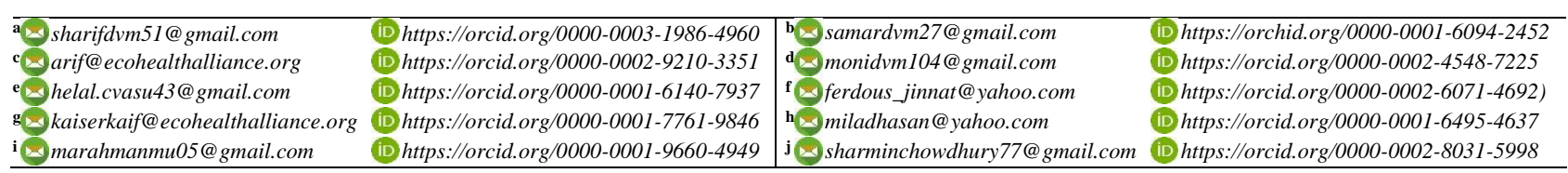

(c) (1) (9) This work is licensed under Creative Commons Attribution 4.0 International License

\section{Introduction}

Mastitis is considered to be the most devastating condition of dairy cattle. It causes remarkable production loss to the livestock industry and has been recognized as one of the most economically significant infectious disease affecting the welfare of dairy animals worldwide (Bradley, 2002; Deluyker et al., 2005; Chishty et al., 2007; Hashemi et al., 2011).

About 75-80\% mastitis is of SCM type (Bradley, 2002; Biswas and Sarker, 2017). The main characteristics of SCM are- a significantly elevated Somatic Cell Count (SCC) to a level >200,000 cells/ml (Radostitis et al., 2000; McDougall et al., 2001; Bradley, 2002) without any visible abnormalities in milk or udder tissues (Radostitis et al., 2007). SCM is 15-40 times more prevalent than the clinical one. It usually follow the clinical form of mastitis and hard to detect, which act as a continuous source of infection for herd mates. SCM reduces average $17.5 \%$ milk production (Joshi and Gokhale, 2006) and adversely affects milk quality and quantity (Seegers et al., 2003; Swinkels et al., 2005; Halasa et al., 2007; Souto et al., 2010; Islam et al., 2012b). Singh and Singh (1994) reported more than three times production losses due to SCM, as compared to clinical mastitis (CM)(Abrahmsén et al., 2014). 
The infection level of SCM in cows is accelerated with pendulous udder \& mid-lactation stage (Biffa et al., 2005). SCM arising in late lactation is associated with the highest yield loss (Hortet et al., 1999; Bennedsgaard et al., 2003). Once a cow suffers from SCM, it never return to its normal milk production.

Among different indirect screening tests, California mastitis test (CMT) is considered as a simple, available, easily applied and economic diagnostic test that yield a rapid and satisfactory test result (Joshi and Gokhale, 2006). Reagents of these tests contain detergents which change the structure and conductivity of cell membrane and nucleus of somatic cells, stimulate proteolytic enzymes, and increase milk viscosity (Middleton et al., 2004).

Previous study reported $40.1 \%$ SCM in dairy cows of Ethiopia along with age, Body Condition Score (BCS), milk yield and number of parity as potential risk factors (Birhanu and Leta, 2017). Another study from North West Ethiopia stated the prevalence being $62 \%$ in cows and identified some risk factors like higher parity, $>150$ days in milk (DIM), housed on cemented floors (Mekonnen et al., 2017). Cow level CMT based prevalence in northern region and in sylhet, Bangladesh were reported as 15-44\% (Rahman et al., 2009; Rabbani and Samad, 2010; Islam et al., 2012b; Siddiqe et al., 2015) and 51.3\% (Rahman et al., 2010), respectively. SCM was reported to be $32.43 \%$ in Chittagong (Barua et al., 2014) and $65.5 \%$ in a specific upazilla (Anwara) of Chittagong (Rahman et al., 2014) by CMT. Deterioration of quality and quantity of milk, damage to udder tissue and most importantly economic loss are the ultimate results of SCM (Deluyker et al., 2005). Hence, early detection and characterization of mastitis as well as taking appropriate preventive and control measures is important. In Bangladesh, especially in Chittagong, SCM is the persisting problems in dairy industries. But indepth study of SCM with their risk factors in the study area is limited. Hence the present study was undertaken to know the prevalence of SCM in dairy cows along with associated risk factors for the occurrence of SCM in Chittagong Metropolitan Area (CMA).

\section{Materials and Methods:}

\section{Study Animal and Period}

The study animals consists of 114 cross breed (Holstein $\times$ Local) lactating cows, raised at 6 dairy farms in CMA, Bangladesh. The study was conducted between February to November, 2015. The dairy farm list of CMA were collected from District Livestock office of Chittagong. We randomly selected six upazila of CMA and one farm from each upazila, as well. All cows were hand milked twice daily. The herd size of the farms ranged from 7 to 36 cows. Cows were reared following the cut and carry system-cows are housed, and fed forage cut-and-carried from grass land to farm without any grazing, with free access to water, and were fed a concentrate supplement after milking. To stimulate milk let-down in dairy cows calf suckling before milking was practiced. After end of each milking, calves were allowed to suck the udder without post-dipping.
Milk Sample Collection and Physical Examination of Milk Samples

Each farm was visited once and the cows were examined to rule out clinical mastitis (temperature $\leq 39.5^{\circ} \mathrm{C}$, no signs of illness and/or inflammatory signs of the udder, and normal milk upon ocular inspection). After udder sanitation, appraisal and discarding of foremilk, around $5 \mathrm{ml}$ milk from each quarter was collected and mixed all four quarter milk samples in a sterile screw capped tube. The milk were collected by an expert milk man and the hands were cleaned properly before every milking. Immediately after milk collection, samples were observed with naked eyes to detect any abnormalities in color, odor, consistency and presence of clot, blood, flakes and any other visible abnormalities.

\section{California Mastitis Test (CMT)}

The cows were tested with the CMT kit according to (Mellenberger and Roth, 2000) detect the SCM.

The CMT test result was scored from 1 to 5 according to the Scandinavian scoring system, where 1 is negative result (no gel formation), 2 is traceable (possible infection), and 3 or above indicates a positive result, where 5 has the most gel formation (Saloniemi, 1995; Persson et al., 2011).

\section{Questionnaire-Based Data Collection}

Data for each animal and herd were collected using a pretested questionnaire. The information includes age, breed, number of parity, lactation stage, source of cow replacement, cleanliness and type of floor, history of reproductive diseases (For example: anestrous, dystocia, endometritis, pyometra, abortion, stillbirth etc.), and per day milk production.

\section{Statistical Analysis}

Data on risk factors and results of CMT were stored in Microsoft Excel 2013. The data ware cleaned, coded and checked for integrity in MS Excel 2013 and exported to STATA-13 (StataCrop, 4905, Lakeway Drive, College station, Texas 77845, USA) to perform the statistical analysis. To find the association between explanatory variables and prevalence of sub-clinical mastitis- chisquare test was done and the level of significance was set at $\mathrm{P} \leq 0.05$. The significant factors from univariable analysis were forwarded to multivariable logistic regression analysis considering cluster of positive animals at farm level. The model were checked for collinearity, confounding and interaction following standard statistical procedure (Dohoo and Martin, 2003). The variables were considered significant which have $\mathrm{P} \leq 0.05$ in Wald test. The Odds ratio (OR) and $95 \%$ confidence interval were used to express the results.

\section{Results}

The study estimated SCM prevalence in dairy cows as $34.2 \%$ in intensive farming system in Chittagong, Bangladesh. The CMT scores ware ranged from 1 to 3. For positive samples, most of them scored 3 and two samples scored 2 (Figure 1). The color, odor, consistency and presence of clot in the milk samples for scored 2 samples were considered positive for SCM. 


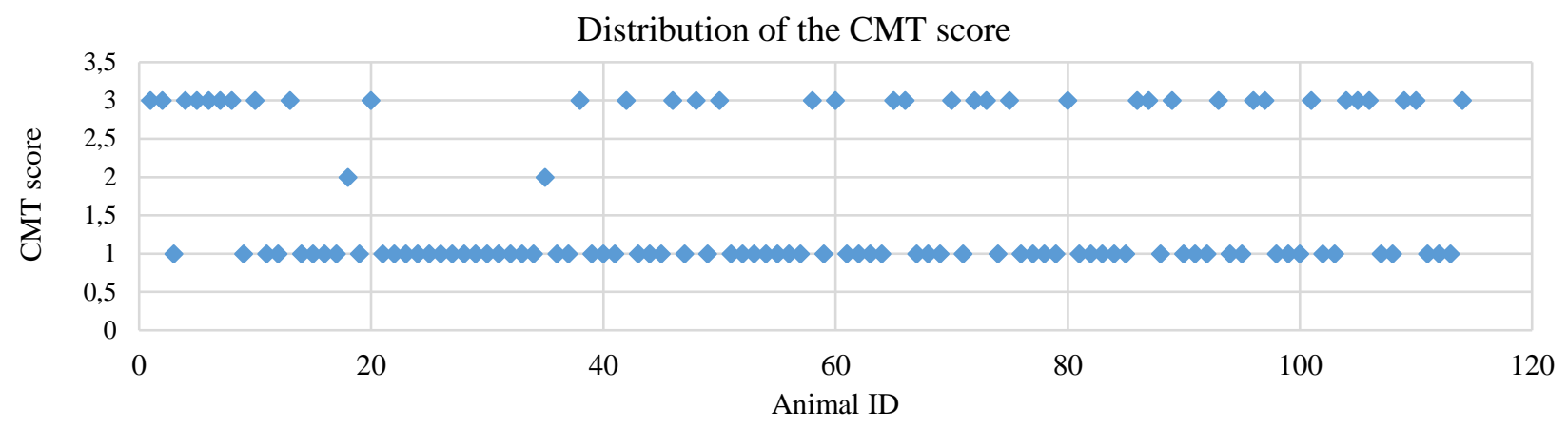

Figure 1 Distribution of CMT scores of dairy cows for SCM in CMA, Bangladesh, 2015

Table 1 Contingency tables and chi-square test conducted to evaluate the association between explanatory variables and subclinical mastitis in dairy cows in Chittagong Metropolitan Area in Bangladesh, 2015.

\begin{tabular}{|c|c|c|c|c|c|c|}
\hline Variables & Categories & $\begin{array}{l}\text { Positive/ Total } \\
\text { tested }\end{array}$ & $\begin{array}{c}\text { Prevalence } \\
(\%)\end{array}$ & $\begin{array}{l}95 \% \text { Confidence } \\
\text { Interval } \\
\end{array}$ & $\mathrm{Chi}^{2}$ & $\mathrm{P}$ \\
\hline \multirow{6}{*}{ Upazila } & Bakolia & $11 / 21$ & 52 & $29.78-74.29$ & \multirow{6}{*}{8.51} & \multirow{6}{*}{0.130} \\
\hline & Bayezid & $12 / 36$ & 33 & $18.56-50.97$ & & \\
\hline & Chandgaon & $5 / 11$ & 45 & $16.75-76.62$ & & \\
\hline & Halishahar & $3 / 7$ & 43 & $09.90-81.59$ & & \\
\hline & Nasirabad & $6 / 21$ & 29 & $11.28-52.17$ & & \\
\hline & Panchlaish & $2 / 18$ & 11 & $01.37-34.71$ & & \\
\hline \multirow{2}{*}{ Floor } & Brick & $2 / 18$ & 11 & $01.37-34.71$ & \multirow{2}{*}{5.07} & \multirow{2}{*}{0.024} \\
\hline & Cemented & $37 / 96$ & 39 & $28.78-49.03$ & & \\
\hline \multirow{3}{*}{$\begin{array}{l}\text { Source of animals for } \\
\text { replacement }\end{array}$} & Own farm & $28 / 68$ & 41 & $29.37-53.77$ & \multirow{3}{*}{5.79} & \multirow{3}{*}{0.055} \\
\hline & Other farm & $2 / 18$ & 11 & $01.37-34.71$ & & \\
\hline & Both & $9 / 28$ & 32 & $15.88-52.35$ & & \\
\hline \multirow{2}{*}{ Types of farm } & Cattle & $28 / 93$ & 30 & $21.03-40.50$ & \multirow{2}{*}{3.78} & \multirow{2}{*}{0.05} \\
\hline & Mixed species & $11 / 21$ & 52 & $29.78-74.29$ & & \\
\hline \multirow{2}{*}{$\begin{array}{l}\text { History of Reproductive } \\
\text { disorder }\end{array}$} & Yes & $12 / 23$ & 52 & $30.59-73.18$ & \multirow{2}{*}{4.13} & \multirow{2}{*}{0.042} \\
\hline & No & $27 / 91$ & 28 & $19.21-37.86$ & & \\
\hline \multirow{4}{*}{ Age (years) } & Min-3 & $0 / 7$ & 0 & 0 & \multirow{4}{*}{6.96} & \multirow{4}{*}{0.073} \\
\hline & $>3$ to $<6$ & $22 / 58$ & 38 & $25.51-51.63$ & & \\
\hline & $>6$ to $<8$ & $8 / 31$ & 26 & $11.86-44.61$ & & \\
\hline & $>8$ & $9 / 18$ & 50 & $26.02-73.98$ & & \\
\hline \multirow{2}{*}{ Pregnancy } & Fresh & $23 / 69$ & 33 & $22-46$ & \multirow{2}{*}{0.06} & \multirow{2}{*}{0.807} \\
\hline & Pregnant & $16 / 45$ & 36 & $22-51$ & & \\
\hline \multirow{2}{*}{ BCS } & $\leq 3$ & $32 / 87$ & 37 & $26.69-47.80$ & \multirow{2}{*}{1.08} & \multirow{2}{*}{0.299} \\
\hline & $>3$ & $7 / 27$ & 25 & $10.69-44.87$ & & \\
\hline \multirow{2}{*}{ Lactation no. } & $<2$ & $3 / 16$ & 19 & $04.05-45.65$ & \multirow{2}{*}{1.98} & \multirow{2}{*}{0.160} \\
\hline & $>2$ & $36 / 98$ & 37 & $27.22-47.08$ & & \\
\hline \multirow{2}{*}{ Milk yield (liter) } & Min-13 & $22 / 58$ & 38 & $25.51-51.63$ & 0726 & 0394 \\
\hline & $>13$ & $17 / 56$ & 30 & $18.78-44.10$ & 0.120 & 0.394 \\
\hline & Min-2 & $11 / 30$ & 37 & $19.93-56.14$ & & \\
\hline & $>2-5$ & $10 / 36$ & 28 & $14.20-45.19$ & & \\
\hline Lactation period (month) & $>5-7$ & $6 / 29$ & 21 & 07.99-39.72 & 10.17 & 0.017 \\
\hline & $>7$ & $12 / 19$ & 63 & $38.36-83.71$ & & \\
\hline Gestation period (month) & $1-4.5$ & $32 / 101$ & 32 & $22.78-41.69$ & 251 & 0.113 \\
\hline & $>4.5$ & $7 / 13$ & 54 & $25.13-80.78$ & 2.51 & 0.113 \\
\hline Cleanliness of floor & Good & $10 / 45$ & 22 & $11.20-37.09$ & & \\
\hline Cleanilness or nloor & Poor & $29 / 69$ & 42 & $30.24-54.52$ & 4.75 & 0.029 \\
\hline
\end{tabular}

Farms with cemented floor $(39 \%)$ had significantly more events of SCM than farms having brick floor $(11 \%)$ $(\mathrm{P}<0.05)$ (Table 1). Similar significant $(\mathrm{P}=0.055)$ relation was observed between source of replacement cow and prevalence of SCM. Prevalence was higher in pregnant cows $(36 \%)$ than fresh cows $(33 \%)$. The cows aged more than 8 years showed greater prevalence $(50 \%)$ of SCM than age minimum to 3 years $(0 \%)$. High milk producing cows showed greater prevalence $(52.94 \%)$ than medium $(35.00 \%)$ and low producing cows (37.90\%). Mixed farming system faced more SCM events than those having only cattle. The study also revealed a significant 
association $(\mathrm{P}<0.05)$ between the presence of history of reproductive disorder and SCM in cows. The prevalence of SCM was $52 \%$ in cows with a previous history of reproductive disorder. The study also focused on prevalence of SCM in different lactation periods of cows. The prevalence was significantly higher $(\mathrm{P}<0.05)$ in cows with advancing the lactation time from $2^{\text {nd }}$ month. Again, cleanliness of floor is an important factor behind the occurrence of SCM (Table 1).
The random effect model identified two significant factors- type of floor and history of reproductive disorder influenced the occurrence of SCM in the study population. Cemented floor increases the odds of SCM 5.03 times (95\% CI: $1.10-23.5 ; \mathrm{P}=0.04)$ than that of brick floor. Similarly, cows with a history of reproductive disorder had more risk of having SCM than that of having no history of reproductive disorder $(\mathrm{OR}=2.6 ; 95 \% \mathrm{CI}: 01-6.8 ; \mathrm{P}=0.05)$ (Table 2).

Table 2 Factors retained in a final mixed-effect multivariable Logistic regression model of the risk factors of subclinical mastitis in dairy cows in Chittagong Metropolitan Area in Bangladesh, 2015.

\begin{tabular}{l|lcc}
\hline \multicolumn{1}{c|}{ Variables } & Categories & Odds ratio (95\% Confidence interval) & P-value \\
\hline \multirow{2}{*}{ Floor type } & Brick & 1 & 0.04 \\
& Cement & $5.03(1.10-23.5)$ & 0.05 \\
\hline \multirow{2}{*}{ History of reproductive disorder } & No & 1 & \\
& Yes & -13.04 & $-161-135$ \\
Insig2u & 0.0014709 & $1.11 \mathrm{e}^{35}-1.94 \mathrm{e}++^{29}$ & \\
Sigma_u & $6.58 \mathrm{e}^{-07}$ & $3.77 \mathrm{e}-{ }^{77}-1$ & \\
Rho & & & \\
\hline
\end{tabular}

\section{Discussion}

The overall prevalence was close to the findings reported $(32.43 \%)$ from the study site earlier (Barua et al., 2014). Although the prevalence is lower than other previous reports from Ethiopia, $40.1 \%$ by Birhanu and Leta (2017) and $62 \%$ by Mekonnen et al. (2017) but within the range $(19.9 \%$ - 44.8\%) stated by some researchers in Bangladesh (Rahman et al., 2009; Rabbani and Samad, 2010; Islam et al., 2012a) and from other countries (25.2 to $55.2 \%$ at cow level) (Gianneechini et al., 2002; Mungube et al., 2005; Joshi and Gokhale, 2006; Harouna et al., 2009; Mdegela et al., 2009; Bitew et al., 2010; Abrahmsén et al., 2014). Mastitis is a multifactorial disease that predominates the interaction between host, agent and environment (Thrusfield and Christley, 2005; Abdel-Rady and Sayed, 2009). A possible explanation of the difference in the prevalence of SCM in cows might be difference in study populations characteristics, geographical influence and others husbandry practices in the farms of different study (Mdegela et al., 2009; Sarker et al., 2013; Abrahmsén et al., 2014; Barua et al., 2014; Islam et al., 2015; Koop et al., 2016).

\section{Replacement Stock}

Significant variation was found in the presence of SCM among different source of replacement stock. Replacing cows from unknown sources is a common scenario in Bangladesh. Usually the farmers bought cows from livestock markets where animal sellers bring their animals to sell from different districts of the region even from different divisions which situated far away from the study area. The newly arrived cows in the herd may harbor different pathogen that are capable of causing mastitis and spread to healthy cows of the farms (Abrahmsén et al., 2014). Some dairy farmers maintain strict biosecurity measures in their farm. Collecting replacement stock from those farmers is helpful to maintain a good quality herd in own farms. However this is not a common practice in Bangladesh. It increases the possibility of SCM in dairy herds.

\section{Types of Farm}

Presence of sub-clinical mastitis also varies between single species farm and mixed species farm. Different species harbor different microorganisms which may cause mastitis under favorable conditions. So, presence of different species within same farm pre-disposes the exposure of variety of organisms. Besides, mixing of different species increases the chance of contamination through milker's hand and utensils. Lactation period (months) and cleanliness of floor influences the occurrence of SCM significantly in dairy farms too.

\section{Age}

Prevalence of SCM increased with the advancement of age in cows in agreement with other studies (Abdel-Rady and Sayed, 2009; Barua et al., 2014). The teat canal of older animals become more dilated or partly open condition that persist permanently due to years of repeated milking (Madut et al., 2009). This may lead to long time exposure of older animals to SCM causing microorganisms compared to younger animals. The prevalence is also increase with age as the spontaneous cure rate of SCM is low (McDougall et al., 2002). The study farms follow hand milking. Incomplete milking is usually happen in this situation that limit the self-cure rate of SCM in cows.

\section{Stage of Lactation}

In the present study, cows having gestation period more than 7 months were more susceptible to SCM is concordant to earlier findings whereas chronic mastitis, most often subclinical, is more frequent later during the lactation. The Staphylococcus species is one of the main causative agent of SCM due to unhygienic milking. This organism usually colonise at the teat and teat canal which may lead to increase the somatic cell counts and SCM. The use of dry cow therapy and post-milking disinfections practice are the common way to prevent this organism (Mdegela et al., 2009a). In our study farms, non-existence of dry period and post milking disinfection practice might influencing the 
higher SCM in later stage. Farm owners have tendency to milk the cows for a very long periods; some times more than a year, which increase the risk of SCM (Abrahmsén et al., 2014).

\section{History of Previous Reproductive Disorders}

The history of previous reproductive disorders was found significantly associated with SCM occurrence. If a cow suffered from any reproductive disorder, it increased the chance of getting infection might be especially through reproductive tract like in case of retained placenta or endometritis which facilitate the udder to come in contact with contaminated body parts like pendulous placenta. In previous study repeat breeding was found associated with clinical mastitis and repeat breeding was increasing with increased incidence of clinical mastitis (Gustafsson and Emanuelson, 2002; Hertl et al., 2010).

\section{Floor Type and Cleanliness}

A significant risk factor for SCM is floor type and cleanliness of the floor. Cemented floor and cleanliness of the floor was acknowledged previously as an important factor for increasing the risk of sub-clinical mastitis occurrence elsewhere (Schreiner and Ruegg, 2003; Doherr et al., 2007; Sarker et al., 2013; Abrahmsén et al., 2014; Mekonnen et al., 2017). There are many pathogens that are found in dirty environment especially in the barn of animals which is capable of causing mastitis in cows. The cleanliness of the floor depends on manure management system, frequency of cleaning of barn, overcrowding, dominancy of animals and easy movement facility availability for animals within the barns. Moisture, mud, and manure present in the environment of the cow are the primary sources of exposure for environmental mastitis pathogens, and hygiene scores of cows provide visible evidence of exposure to these potential sources (Schreiner and Ruegg, 2003). In this study, we were able to confirm the relationship between the increased risk of SCM and floor type. Even though we did not perform any in-depth statistics on it, a reflection is that the overall hygiene and especially the hygiene routines around milking time; and before and after calving, are might be the main reasons of the SCM occurrence in dairy cattle's of the study area. No separate grouping of cows or predetermined order of milking based on the udder health status were observed.

The study aim was to know the present situation of SCM in cows of commercial dairy farms and to contribute in improved prevention and control of SCM. We identified some possible risk factors that could be an effective guideline to build awareness among farm owners and to establish effective control strategy SCM control in the dairy farms. As well as the findings can be manipulated to reduce the SCM level in dairy herds which in turn help to raise the production and economic benefit of the farm.

\section{Conclusion}

In the present study, high prevalence of SCM in dairy cows of CMA was found by CMT. Some risk factors were found that might facilitate the occurrence of SCM in dairy cows like replacement stock, types of farm, and floor type and their cleanliness at farm level; and age, stage of lactation and history of reproductive disorders at individual animal level. Maintaining the proper hygienic condition in the dairy farm along with their milk production procedures may help to reduce the SCM in the study area. Since this form of mastitis is an undetectable problem clinicallyawareness building among the farm owners may also prevent the considerable economic losses.

\section{Acknowledgement and Conflict of interest}

The authors acknowledged the farm owners contribution for supporting and helping the study. Special gratitude is also extended to Department of Pathology and Parasitology, Faculty of Veterinary Medicine, Chittagong Veterinary and Animal Sciences University, Bangladesh. We thank Hubert Deluyker, former Scientific Adviser to the European Food Safety Authority (EFSA) for his constructive suggestions, comments and corrections of the manuscript. This study was benefited from intellectual contributions from the PREDICT project of the United States Agency for International Development (USAID) Emerging Pandemic Threats Program.

No conflict of interest.

\section{References}

Abdel-Rady A, Sayed M. 2009. Epidemiological Studies on Subclinical Mastitis in Dairy cows in Assiut Governorate. Vet. World. 2(10): 373-380.

Abrahmsén M, Persson Y, Kanyima BM, Båge R. 2014. Prevalence of subclinical mastitis in dairy farms in urban and peri-urban areas of Kampala, Uganda. Trop. Anim. Health Pro. 46(1): 99-105.

Barua M, Prodhan MA, Islam K, Chowdhury S, Hasanuzzaman M, Imtiaz MA, Das GB. 2014. Sub-clinical mastitis prevalent in dairy cows in Chittagong district of Bangladesh: detection by different screening tests. Vet. World. 7(7): 483-488.

Bennedsgaard TW, Enevoldsen C, Thamsborg SM, Vaarst M. 2003. Effect of mastitis treatment and somatic cell counts on milk yield in Danish organic dairy cows. J. Dairy Sci. 86(10): 3174-3183.

Biffa D, Debela E, Beyene F. 2005. Prevalence and risk factors of mastitis in lactating dairy cows in Southern Ethiopia. Int. J. Appl. Res. Vet. Med. 3(3): 189-198.

Birhanu M, Leta S, Mamo G, Tesfaye S. 2017. Prevalence of bovine subclinical mastitis and isolation of its major causes in Bishoftu Town, Ethiopia. BMC Res. Notes. 10(1): 767.

Biswas D, Sarker T. 2017. Prevalence of sub-clinical mastitis at banaripara upazilla, Barisal. Bangl. J. Vet. Med.15(1): 21-26.

Bitew M, Tafere A, Tolosa T. 2010. Study on bovine mastitis in dairy farms of Bahir Dar and its environs. J. Anim. Vet. Adv.9(23): 2912-2917.

Bradley AJ. 2002. Bovine mastitis: an evolving disease. Vet. J. 164(2): 116-128.

Chishty MA, Arshad M, Avais M, Ijaz M. 2007. Cross-sectional epidemiological studies on mastitis in cattle and buffaloes of tehsil Gojra Pakistan. Buff. Bull. 26(2): 50-55.

Deluyker HA, Van Oye SN, Boucher JF. 2005. Factors affecting cure and somatic cell count after pirlimycin treatment of subclinical mastitis in lactating cows. J. Dairy Science. 88(2): 604-614.

Doherr MG, Roesch M, Schaeren W, Schallibaum M, Blum JW. 2007. Risk factors associated with subclinical mastitis in dairy cows on Swiss organic and conventional production system farms. Vet. Med.(Praha). 52(11): 487-495

Dohoo IR, Martin W, Stryhn H. 2003. Veterinary Epidemiologic Research. University of Prince Edward Island, Charlottetown, Canada.

Gianneechini R, Concha C, Rivero R, Delucci I, López JM. 2002. Occurrence of clinical and sub-clinical mastitis in dairy herds in the West Littoral Region in Uruguay. Acta Vet. Scand. 43(4): 221-230. 
Gustafsson H, Emanuelson U. 2002. Characterisation of the repeat breeding syndrome in Swedish dairy cattle. Acta Vet. Scand. 43(2): 115-125.

Halasa T, Huijps K, Østerås O, Hogeveen H. 2007. Economic effects of bovine mastitis and mastitis management: a review. Vet. Wuart. 29(1): 18-31.

Harouna A, Zecchini M, Locatelli C, Scaccabarozzi L, Cattaneo C, Amadou A, Bronzo V, Marichatou H, Boettcher PJ, Zanoni MG, Alborali L. 2009. Milk hygiene and udder health in the periurban area of Hamdallaye, Niger. Trop. Anim. Health Prod. 41(5): 705-710.

Hashemi M, Kafi M, Safdarian M. 2011. The prevalence of clinical and subclinical mastitis in dairy cows in the central region of Fars province, south of Iran. Iranian J. Vet. Res. 12(3): 236-241.

Hertl JA, Gröhn YT, Leach JD, Bar D, Bennett GJ, Gonzalez RN, Rauch BJ, Welcome FL, Tauer LW, Schukken YH. 2010. Effects of clinical mastitis caused by gram-positive and gramnegative bacteria and other organisms on the probability of conception in New York State Holstein dairy cows. J. Dairy Science. 93(4): 1551-1560.

Hortet P, Beaudeau F, Seegers H, Fourichon C. 1999. Reduction in milk yield associated with somatic cell counts up to 600 000 cells $/ \mathrm{ml}$ in French Holstein cows without clinical mastitis. Livest. Prod. Sci. 61(1): 33-42.

Islam MA, Islam MZ, Islam MA, Rahman MS, Islam MT. (2012a)). Prevalence of subclinical mastitis in dairy cows in selected areas of Bangladesh. Bangl. J. Vet. Med. 9(1):73-78.

Islam MA, Rahman AK, Rony SA, Islam MS. 2012b. Prevalence and risk factors of mastitis in lactating dairy cows at Baghabari milk shed area of Sirajganj. Bangl. J. Vet. Med. 8(2): 157-162.

Islam S, Moni SP, Barua SR, Parvez MA. 2015. Clinical manifestations and diseases of cattle and goats in Gopalganj, Bangladesh. Eco-friendly Agril. J. 8: 81-85.

Joshi S, Gokhale S. 2006. Status of mastitis as an emerging disease in improved and periurban dairy farms in India. Annals of the New York Academy of Sciences. 1081(1): 74-83.

Koop G, Islam MN, Rahman MM, Khatun M, Ferdous J, Sayeed MA, Islam S, Ahaduzzaman M, Akter S, Mannan A, Hassan MM. 2016. Risk factors and therapy for goat mastitis in a hospital-based case-control study in Bangladesh. Prev. Vet. Med. 124: 52-57.

Madut NA, Godir AEA, El-Jalil IM. 2009. Host determinants of bovine mastitis in semi-intensive production system of Kharfoum State, Sudan. J. Cell Anim. Biol. 3(5): 71-77

McDougall S, Murdough P, Pankey W, Delaney C, Barlow J, Scruton D. 2001. Relationships among somatic cell count, California mastitis test, impedance and bacteriological status of milk in goats and sheep in early lactation. Small Ruminant Res. 40(3): 245-254.

McDougall S, Pankey W, Delaney C, Barlow J, Murdough PA, Scruton D. 2002. Prevalence and incidence of subclinical mastitis in goats and dairy ewes in Vermont, USA. Small Ruminant Res.46(2-3): 115-121.

Mdegela RH, Ryoba R, Karimuribo ED, Phiri EJ, Løken T, Reksen O, Mtengeti E, Urio NA. 2009. Prevalence of clinical and subclinical mastitis and quality of milk on smallholder dairy farms in Tanzania. J. S. Afr. Vet. Assoc. 80(3):163-168.

Mekonnen SA, Koop G, Melkie ST, Getahun CD, Hogeveen H, Lam TJ. 2017. Prevalence of subclinical mastitis and associated risk factors at cow and herd level in dairy farms in North-West Ethiopia. Prev. Vet. Med. 145:23-31.

Mellenberger R, Roth CJ. 2000. California Mastitis Test (CMT). Fact Sheet, Dept. of Animal Sciences, Michigan State University and Dept. of Dairy Science, University of Wisconsin-Madison.
Middleton JR, Hardin D, Steevens B, Randle R, Tyler JW. 2004. Use of somatic cell counts and California mastitis test results from individual quarter milk samples to detect subclinical intramammary infection in dairy cattle from a herd with a high bulk tank somatic cell count. J. Am. Vet. Med. Assoc. 224(3): 419-423.

Mungube EO, Tenhagen BA, Regassa F, Kyule MN, Shiferaw Y, Kassa T, Baumann MP. 2005. Reduced milk production in udder quarters with subclinical mastitis and associated economic losses in crossbred dairy cows in Ethiopia. Trop. Anim. Health Prod. 37(6): 503-512.

Persson Y, Nyman AK, Grönlund-Andersson U. 2011. Etiology and antimicrobial susceptibility of udder pathogens from cases of subclinical mastitis in dairy cows in Sweden. Acta Vet. Scand. 53(1): 36.

Rabbani AF, Samad MA. 2010. Host determinants based comparative prevalence of subclinical mastitis in lactating Holstein-Friesian cross cows and Red Chittagong cows in Bangladesh. Bangl. J. Vet. Med. 8(1): 17-21.

Radostitis O, Gay C, Blood D, Hinchcliff K. 2000. Veterinary medicine: A textbook of the diseases of cattle, sheep, pigs, goats and horses. WB Saunders company. Harcourt publishers, London. UK.

Radostitis O, Gay C, Hinchcliff K, Constable P. 2007. Veterinary medicine. A text book of the diseases of cattle, horses, sheep, pigs and goats. 10th Edn. Saunders Elsevier; Edinburgh, London, New york. Oxford, Philadelphia, St. Louis, Sydney, Toronto.

Rahman MA, Bhuiyan MM, Kamal MM, Shamsuddin M. 2009. Prevalence and risk factors of mastitis in dairy cows. Bangl. Vet. 26(2): 54-60.

Rahman MM, Islam MR, Uddin MB, Aktaruzzaman M. 2010. Prevalence of subclinical mastitis in dairy cows reared in Sylhet district of Bangladesh. Int. J. Bio. Res. 1(2): 23-28.

Rahman MM, Munsi MN, Ekram MF, Kabir MH, Rahman MT, Saha S. 2014. Prevalence of subclinical mastitis in cows at Anwara, a coastal Upazila of Chittagong district in Bangladesh. J. Vet. Adv. 4(6): 594-598.

Saloniemi H. 1995. Use of somatic cell count in udder health work. The Bovine Udder and Mastitis. 105-110.

Sarker SC, Parvin MS, Rahman AA, Islam MT. 2013. Prevalence and risk factors of subclinical mastitis in lactating dairy cows in north and south regions of Bangladesh. Trop. Anim. Health Prod. 45(5): 1171-1176.

Schreiner DA, Ruegg PL. 2003. Relationship between udder and leg hygiene scores and subclinical mastitis. J. Dairy Science. 86(11): 3460-3465.

Seegers H, Fourichon C, Beaudeau F. 2003. Production effects related to mastitis and mastitis economics in dairy cattle herds. Vet. Res. 34(5): 475-491.

Siddiqe MZF, Islam S, Islam SS, Islam S, Islam S, Das BC. 2015. Haematobiochemical changes in subclinical mastitis affected high yielding dairy cows in Chittagong district. Int. J. Nat. Soc. Sci 2(4): 30-34.

Souto LI, Minagawa CY, Telles EO, Garbuglio MA, Amaku M, Melville PA, Dias RA, Sakata ST, Benites NR. 2010. Correlation between mastitis occurrence and the count of microorganisms in bulk raw milk of bovine dairy herds in four selective culture media. J. Dairy Res. 77(1): 63-70.

Swinkels JM, Hogeveen H, Zadoks RN.2005. A partial budget model to estimate economic benefits of lactational treatment of subclinical Staphylococcus aureus mastitis. J. Dairy Science. 88(12): 4273-4287.

Thrusfield M, Christley R. 2005. Veterinary epidemiology. Wiley Online Library. 